\title{
A FOGYASZTÓI ATTITÚD KOGNITÍV KOMPONENSÉNEK A PÁLINKA IMÁZSÁBAN BETÖLTÖTT SZEREPE
}

\author{
- ho \\ THE ROLE OF THE COGNITIVE COMPONENT OF CONSUMER ATTITUDE \\ IN THE IMAGE OF THE PÁLINKA

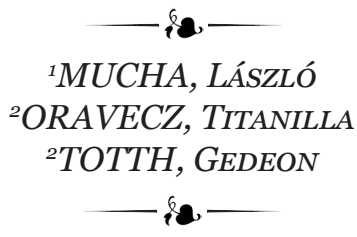 \\ ${ }^{1}$ Szent István Egyetem, Gazdálkodás és Szervezéstudományok Doktori Iskola \\ (Doctoral School of Management and Business, Szent István University) \\ H-2100 Gödöllő, Páter Károly utca 1. \\ e-mail: mucha.laszlo@phd.uni-szie.hu \\ ${ }^{2}$ Budapesti Gazdasági Egyetem Külkereskedelmi Kar, Marketing Tanszék \\ (Marketing Department, Faculty of International Management and Business, Budapest Business School) \\ H-1165, Budapest, Diósy Lajos u. 22-24.
}

\begin{abstract}
al
The research aim is to explore the potential role of consumer attitude components in image development related to a traditional Hungarian alcoholic beverage, the pálinka. This study focuses on the effect of the cognitive component of attitude on image of the pálinka. The relevance of this research is the expansion of the pálinka market in recent years and the changing of the regulatory environment about homemade spirits. Distillate made at home, which product improperly called homemade pálinka, is very popular in Hungary. Based on the qualitative studies, the most important characteristics in the consumer perception of alcoholic beverage are quality, price, prestige, fashion and origin. The importance of these attributes of the most popular alcoholic beverages in Hungary was assessed by the participants on Likert scales. Homemade spirit has the most favorable attitude and in-store pálinka has the most unfavorable attitude. To understand the effect of the cognitive component, we used two types of the multiattribute attitude model of Fishbein. By using a 7-point semantic differential scale, we could graphically illustrate the consumer belief about the homemade and in-store pálinka. Image profiles on the semantic differential scales show the differences in image of the analysed alcoholic beverages. The study confirmed the advantage of homemade spirit image over in-store pálinka, points out the importance of education and information in the case of the cognitive component of consumer attitude. The reconsidering of the marketing communication of the in-store pálinka producers is very important and urgent.
\end{abstract}

KULCSSZAVAK: fogyasztói magatartás, imázs, attitűdvizsgálat, pálinka
KEYwORDs: consumer behaviour, image, attitude research, the pálinka

JEL-KóD (JEL CODE): M31

DOI: https://doi.org/10.20494/TM/7/2/2 


\section{Bevezetés - INTROdUCTION}

A kutatás egy Magyarországon nagy hagyománnyal rendelkező, magas minőségü élelmiszeripari termék, a pálinka esetében vizsgálja az attitűd kognitív komponensének imázs alakító szerepét. Ezen fogyasztást befolyásoló tényező azonosítása lehetővé teszi a megfelelő marketingkommunikációs stratégia kialakítását az ágazati szereplők számára. A jogszabályi környezet, valamint a házi párlat egyértelmú preferáltsága nehéz helyzetbe hozza a kereskedelmi pálinkák előállítóit, amely indokolja a fogyasztói motivációk, attitűdök alapos vizsgálatát. A Pálinka Nemzeti Tanács már megkongatta a vészharangot, hiszen a kereskedelmi főzés visszaesése a bérfőzdék termelésének a növekedésével párosult, továbbá felhívták a figyelmet a magánfőzés jelentette feketekereskedelemre is (PÁLINKA NEMZETI TANÁCS, 2019).

$\mathrm{Az}$ Európai Parlament és a Tanács által jegyzett, 110/2008/EK rendelet (2008. ÉVI LXXIII. TÖRVÉNY, 2008) értelmében uniós oltalomban részesül a „Pálinka” és „Törkölypálinka” megjelölés, vagyis a pálinka elnevezés kizárólag Magyarországon (illetve barackpárlatok esetében további 4 osztrák tartományban) használható. Hazánkban a pálinkakultúra több évszázados múltra tekint vissza (JÓNÁS, 2006). A jogszabály értelmében a bérfőző által gyártott, illetve otthon fözött termékre nem alkalmazható a pálinka kifejezés, csak a párlat. Ezért a tanulmányban a házi párlat kifejezést használjuk a közbeszédben elterjedt, és helytelenül használt „házi pálinka” helyett.

\section{SZAKIRODALMI ÁTTEKINTÉS -} LITERATURE REVIEW

TOTTH és munkatársai (2015) felhívják a figyelmet arra, hogy a hatalmas termékválaszték, és termékmennyiség jellemezte piaci versenyben hátrányba kerülnek az önálló karakterrel nem rendelkező, névtelen piaci szereplők. Versenyképességükhöz, a megfelelő marketingkommunikáció célzott alkalmazásához elengedhetetlen a fogyasztók magatartásának ismerete. SZAKÁLY és munkatársai (2004) rámutatnak, hogy a magyar élelmi- szer-gazdaság szereplőinek kötelessége lenne a kiváló értékmérő tulajdonságú hazai termékek piaci lehetőségeinek kihasználása. A globalizálódott élelmiszerkereskedelemmel szemben a kiváló, egyedi nemzeti termékeink a diverzifikációt képviselik (LAKNER et al., 2004). BRUHN (2008) az információgyüjtésre, és a bizalmi tényezőkre épülő trendek megerősödéséről számol be. MIKLÓS (2019) rámutat, hogy a termékek eredetéről, származási helyéről a fogyasztók tudása általában hiányos. Ezen megállapítás a pálinkafogyasztás vonatkozásában is helytálló. Kutatásunk célja annak megismerése, hogy milyen szempontok befolyásolják ebben az esetben a fogyasztói magatartást.

\subsection{Imázs - Image}

LAKNER és munkatársai (2007) rámutatnak a magyar fogyasztók hazai termékekbe vetett bizalmának a fontosságára. Az imázsépítésnek ebben kiemelt szerepe van. A termékról (szolgáltatásról, márkáról, üzletról stb., továbbiakban csak „termékről”) kialakult pozitív imázs a fogyasztói bizalom megteremtésének fontos eszköze. LEHOTA (2001) csoportosításában az érzelmi termékek esetében a termék értékelése szubjektív, amely lehet imázsra épülő. A fogyasztói magatartás jelenségeinek leírására Gardner és Levy használta először az imázs kifejezést 1955-ben, idézi SZELES (1998) „...A fogyasztói ötleteknek, érzéseknek és magatartásoknak ez a márkákkal kapcsolatos komplexuma döntő a legmegfelelőbbnek tűnő termékek kiválasztása és az irántuk megnyilvánuló hűség szempontjából”. GUTJAHR (1992) szerint imázs elméletté terebélyesedett az ezzel kapcsolatos ismeretanyag, meghatározásában az imázs a fogyasztók részben helyes, részben hamis egyéni és csoportos tapasztalatai, elképzelései. Habár az imázs szubjektív észlelet, és nagymértékben befolyásolja a kulturális környezet, valamint értékrend, TOTTH (1998) szerint mégis tanulmányozható objektív módszerekkel. Egy adott termék vonatkozásában az imázs vizsgálata feltárja a fogyasztói elképzeléseket, szükségleteket (TOTTH, 1994). TOTTH (1996) szerint csak az imázs ismeretében lehet a marketing eszköztárát hatékonyan alkalmazni. SZELES (2001) megfogalmazásában a fogyasztó múltbéli tapasztalataiból alakul ki az imázs. 


\subsection{Pálinka imázs - Image of the Palinka}

Az elmúlt években a pálinka imázsa nem romlott (TOTTH et al., 2018b), azonban javulás sem történt (TOTTH et al., 2018a). Korábbi szeszesital fogyasztással kapcsolatos kutatások (TOTTH, 2009; FODOR et al., 2011; SZEGEDYNÉ et al., 2017; TOTTH et al., 2017; TOTTH et al., 2018b) alapján megállapítható, hogy a pálinka kimondottan népszerü ajándékozási alternatívát jelent a fogyasztók számára, így a vásárlási döntések vizsgálata során mind a saját fogyasztásra, mind az ajándékozási céllal vásárolt pálinkákra kitért a kutatás.

Számos, a pálinkafogyasztással foglalkozó hazai kutatás (TOTTH, 2009; FODOR et al., 2011; SZEGEDYNÉ et al., 2017; TOTTH et al., 2017) rávilágított a pálinkával kapcsolatos fogalmi zavarokra, amely további vizsgálatokat indokol a témában. Ezen korábbi kutatások mind kihangsúlyozták, hogy a fogyasztók többségének a házi párlatok jelentik az igazi pálinkát. Az attitűd kognitív komponense az attitűd tárgyával kapcsolatos ismeretekre, vagy pontosabban meggyőződésekre, véleményekre vonatkozik, melyet az egyén az attitűd tárgyával való közvetlen tapasztalataiból, illetve különböző egyéb információforrásokból szerzett (HOFMEISTER-TÓTH, 2006). A pálinkával kapcsolatos fogyasztói attitűd kognitív komponense meglehetősen gyenge. A hazai fogyasztókat vizsgálva a védjegyek vonatkozásában hasonló eredményre jutottak KONTOR és munkatársai (2019). A fogyasztóban a termékről kialakult kép megértéséhez szükséges az attitűd alapos vizsgálata.

\subsection{Az imázs és az attitúd kapcsolata \\ - The Relationship Between Image and Attitude}

TOMCSÁNYI (1988) megfogalmazásában az imázs kép valamiről, az attitűd viszonyulás valamihez. A kettő mindenesetre kölcsönhatásban áll egymással, és a vásárlói magatartás kialakításában mindkettő fontos. BRIJS és munkatársai (2011) szerint az imázs a termék iránti attitűd előzményének tekinthető. Az imázs az attitűd és a sztereotípia között helyezkedik el. Az imázs a személyes percepcióktól, benyomásoktól függ, mellyel kapcsolatban az egyénnek személyes attitűdjei lehetnek (MALOTA, 2003). A fogyasztókban kialakult érzelmi imázs ELLIOT és munkatársai (2011) megítélése szerint képes befolyásolni az attitűdöt.

\subsection{Az attitúd - The Attitude}

A vásárlási magatartásra erősen hat a fogyasztói attitűd, amely a termékek, márkák felé irányuló pozitív, vagy negatív érzés. ALLPORT (1935:358) megfogalmazásában: „Az attitűd tapasztalat révén szerveződött mentális és idegi készenléti állapot.” REZA és DOUGLAS (1971) szerint egy termék iránti attitüd mértéke a fogyasztók által észlelt termék attribútumok összességének függvénye, a tulajdonságok fontosságának a súlyozásával. FISHBEIN és AJZEN (1975), valamint AUTHMAN (1986) szerint az egyén attitűdje az adott pillanatban vélt hite, amelyet az összes hiedelme határoz meg, ezért az attitűd megváltoztatása a hiedelmek megváltoztatásán keresztül lehetséges. Az attitűd EAGLY és CHAIKEN (1993) megfogalmazásában egy adott termék kedvező, vagy kedvezőtlen megítélésével kapcsolatos pszichológiai tendencia. MANDY és munkatársai (2008) szerint az attitűd közvetítő szerepet tölt be a hiedelmek és a magatartási szándék között.

NATHAN és ELEANOR (2011) megfogalmazásában az attitűd az egyén hajlama arra, hogy egy terméket pozitívan, vagy negatívan értékeljen. Az attitüdöt a marketing szemléletben LARS (2012) úgy definiálja, mint a fogyasztói hiedelmek, érzések és a magatartási szándék összetett elemét. A fogyasztónak negatív vagy pozitív meggyőződései vagy érzései lehetnek egy termék vagy szolgáltatás irányában. Ahogyan ALSAMYDAI és munkatársai (2014) rámutatnak, a viselkedési szándékot a fogyasztónak a termékhez vagy szolgáltatáshoz füződő hiedelme vagy érzése határozza meg. Az attitűdkutatás feladata az alig tudatosítható érzések változásainak meghatározása, hiszen a fogyasztók döntéseiket és ítéleteiket a fejükben, kognitív vagy érzelmi alapon hozzák meg, mely dimenziók többnyire rejtve vannak még önmaguk előtt is (SAS, 2012). A fogyasztók döntését befolyásolják hiedelmeik, érzelmeik, ezen rejtett dimenziók megismerésével foglalkozik az attitűdkutatás. 
Az attitűd és az egyén viselkedése közötti szoros kapcsolatra FISHBEIN és AJZEN (1975) mellett OLSON és ZANNA (1993) is rámutatott. Az attitűd vizsgálata már régóta a fogyasztói magatartással foglalkozó kutatások egyik kiemelt területe (OLIVER és SWAN, 1989). Az attitűd az adott magatartáshoz viszonyuló hozzáállást is magában foglalja, ezért előrejelzi a fogyasztói szándékot. Az attitűd alapvető fogalom a fogyasztói magatartás megértésében (NIJSSEN és DOUGLAS, 2011). A marketing és reklám területén YOUN és KIM (2008) szerint az attitűdöt függő változóként használhatjuk. HOFMEISTER-TÓTH (2006) szerint a fogyasztó érzelmi, vagy értelmi érintettsége meghatározó a döntéshozatalban.

A szakirodalmi feldolgozás valamint az égetett szeszes italok hazai fogyasztását feltáró kvalitatív kutatás (melynek eredményeit terjedelmi okok miatt jelen cikkben nem ismertetjük) segítségével fogalmaztuk meg hipotéziseinket. H1 hipotézisünkben azt feltételezzük, hogy a házi párlat imázsa pozitívabb, mint a bolti pálinkáé. H2 hipotézisünk szerint a pálinkával kapcsolatos ismeretek még mindig

rendkívül hiányosak. A bolti pálinka kedvezőtlenebb imázzsal rendelkezik, mint a keserú italok, a vodka, és a whisky (H3).

\section{ANYAg ÉS MÓDSZER - MATERIAL AND METHOD}

Az adatgyưjtés standard kérdőívezéssel, kvótás mintavétel módszerével, személyes megkérdezéssel történt 2019 év vége-2020 év elején. A megkérdezettek a 18 év feletti felnőtt magyar lakosságból kerültek ki, a minta összetétele a 2019-es országos adatok alapján (KSH 2019a; $\mathrm{KSH} 2019 b)$ nem, korcsoport, és régió szempontjából megegyezik a 18 év feletti magyarországi lakosság összetételével. A mintában olyan válaszadók vehettek részt, akik a megkérdezést megelőző három hónapban fogyasztottak pálinkát. A minta demográfiai megoszlását és a reprezentativitásra vonatkozó statisztikai próbákat az 1. táblázat tartalmazza. Az adatok elemzése SPSS 25.0 és Excel segítségével történt.

TABLE 1

A minta szocio-demográfiai megoszlása (\%; fó)

(Demographic Data of Respondents (\%, capita))

\begin{tabular}{|c|c|c|c|}
\hline & & $\begin{array}{c}\text { KSH } 2019(\%) \\
(H C S O, 2019, \%)\end{array}$ & $\begin{array}{l}\text { Saját minta (fó) } \\
\text { (Sample, capita) }\end{array}$ \\
\hline \multirow{2}{*}{ Nem (Gender) } & Férfi (Men) & 47,85 & 300 \\
\hline & Nő (Women) & 52,15 & 326 \\
\hline \multirow{6}{*}{$\begin{array}{l}\text { Korcsoport (Age } \\
\text { group) }\end{array}$} & 18-24 éves (18-24-year-old) & 9,42 & 67 \\
\hline & 25-34 éves (25-34-year-old) & 15,4 & 109 \\
\hline & 35-44 éves (35-44-year-old) & 19,08 & 117 \\
\hline & 45-54 éves (45-54-year-old) & 16,84 & 106 \\
\hline & 55-64 éves (55-64-year-old) & 15,82 & 99 \\
\hline & 65 év felett (older than 65 years) & 23,44 & 128 \\
\hline \multirow{8}{*}{ Régió (Region) } & Budapest (Budapest) & 17,93 & 114 \\
\hline & Pest (Pest) & 13,09 & 82 \\
\hline & Észak-Magyarország (North Hungary) & 11,53 & 72 \\
\hline & Észak-Alföld (North-Great Plain) & 14,85 & 93 \\
\hline & Dél-Alföld (South-Great Plain) & 12,66 & 79 \\
\hline & Közép-Dunántúl (Central Transdanubia) & 10,83 & 68 \\
\hline & Nyugat-Dunántúl (West-Transdanubia) & 10,12 & 61 \\
\hline & Dél-Dunántúl (South-Transdanubia) & 9,00 & 57 \\
\hline
\end{tabular}

Forrás (Source): Saját szerkesztés, 2020, N=626 (Authors'own compilation, 2020, N=626)

Megjegyzés (Note): Reprezentativitás (Representativity): nem (gender) (observed prop. $=0,5208$; test prop. $=0,5215$; $\mathrm{p}=0,501)$; korcsoport (age group) $\left[\chi^{2}(\mathrm{df}=5, \mathrm{~N}=626)=5,334, \mathrm{p}=0,376\right]$; régió (region) $\left[\chi^{2}(\mathrm{df}=7, \mathrm{~N}=626)=0,115, \mathrm{p}=1,000\right]$ 
A kvantitatív vizsgálatot az égetett szeszes italok hazai fogyasztását feltáró kvalitatív kutatás (fókuszcsoportos megkérdezés, egyéni interjúk) előzte meg, melynek eredményeit terjedelmi okok miatt jelen cikkben nem ismertetjük. A legnépszerúbb, leginkább fogyasztott rövid italok feltérképezésére irányuló kvalitatív kérdésekre kapott válaszok megerősítették az AC Nielsen piackutató eredményeit (VILÁGGAZDASÁG, 2017). Ezen italok: a házi párlat, bolti pálinka, vodka, whisky, tequila, brandy, Jägermeister, konyak, Martini, gin. A kvantitatív kérdőívben szereplő legnépszerübb rövid italok: keserü italok (Jägermeister, Unicum), vodka, gin, whisky, borpárlatok (brandy, konyak), bolti pálinka, házi párlat. A kvantitatív kutatás első lépéseként próba-kérdőívezést végeztünk, melyet 205-en töltöttek ki. A végleges kérdőív kialakítása a próbakérdőív értékelése után pszichológus bevonásával történt. A kutatás célja az attitűd komponenseknek a pálinka imázsában betöltött szerepének vizsgálata, a kérdőív megfelelő kérdéseinek összeállítása indokolta a szakemberi segítséget.

\section{EREDMÉNYEK - RESUltS}

A Magyarországon legnépszerübb, leginkább fogyasztott rövid italokhoz kapcsolódó fogyasztói attitűd megismerésére, számszerüsítésére
FISHBEIN (1967) többtényezős attitűdmodelljét alkalmaztuk. Egy fogyasztó adott termékkel kapcsolatos teljes attitűdjét úgy kapjuk meg, hogy a vásárlást befolyásoló tulajdonságok fontossági pontszámát megszorozzuk az adott tulajdonság adott termékre vonatkozó értékelési pontszámával, majd ezen értékeket összesítjük (HOFMEISTER-TÓTH, 2006).

A kvalitatív kutatás, valamint a megismert szakirodalom alapján az égetett szeszes italok vizsgált tulajdonságaiként az árat, minőséget, presztízst, divatot és a magyar eredetet határoztuk meg. A márka fontos vásárlási szempont, de a házi párlat vonatkozásában nem értelmezhető, ezért nem vizsgáltuk. A válaszadók háromelemü skálán (nem fontos, közömbös, fontos) határozták meg, hogy az adott tulajdonság mennyire fontos nekik égetett szeszes ital vásárlásakor. A 626 megkérdezett válaszai alapján a minőség (átlag: 2,75) bizonyult a legfontosabb vásárlási szempontnak, ezt követték az ár $(2,48)$, magyar eredet $(1,99)$, presztízs $(1,91)$, divat $(1,55)$. Majd a válaszadóknak 1-7 Likert skálán értékelniük kellett, hogy a kiválasztott öt tulajdonságnak milyen mértékben felelnek meg az adott tömény szeszes italok. Az eredményeket a tulajdonságok fontossági értékeivel súlyozva határoztuk meg a megkérdezettek adott itallal kapcsolatos attitűdjét (2. táblázat). A magasabb pontszám kedvezőbb attitűdöt jelent.

Magyarországon legnépszerúbb égetett szeszes italokkal kapcsolatos fogyasztói attitüd mérés eredményei

(Results of Consumer Attitude Measurement Related to the Most Popular Spirits in Hungary)

\begin{tabular}{|c|c|c|c|c|c|c|c|}
\hline Jellemző (Features) & $\begin{array}{c}\text { Keserü } \\
\text { ital } \\
\text { (Bitters) }\end{array}$ & $\begin{array}{l}\text { Vodka } \\
\text { (Vodka) }\end{array}$ & $\underset{\text { (Gin) }}{\operatorname{Gin}}$ & $\begin{array}{l}\text { Borpárlat } \\
\text { (Cognac, } \\
\text { brandy) }\end{array}$ & $\begin{array}{c}\text { Házi } \\
\text { párlat } \\
\text { (Home- } \\
\text { made } \\
\text { spirit) }\end{array}$ & $\begin{array}{c}\text { Bolti } \\
\text { pálinka } \\
\text { (Palinka } \\
\text { from the } \\
\text { shop) }\end{array}$ & $\begin{array}{c}\text { Whisky } \\
\text { (Whiskey) }\end{array}$ \\
\hline Ár (Price) & 9,47 & 11,02 & 9,22 & 9,79 & 13,02 & 9,53 & 8,74 \\
\hline Minőség (Quality) & 14,67 & 12,20 & 13,05 & 13,91 & 15,93 & 10,13 & 15,44 \\
\hline Presztízs (Prestige) & 9,10 & 7,95 & 8,14 & 8,57 & 5,87 & 4,93 & 9,16 \\
\hline Divat (Mode) & 6,86 & 6,99 & 6,43 & 6,32 & 6,81 & 5,12 & 7,45 \\
\hline $\begin{array}{l}\text { Magyar eredet (Hungarian } \\
\text { origin) }\end{array}$ & 8,66 & 5,35 & 5,36 & 7,01 & 12,28 & 8,53 & 4,59 \\
\hline Összesen (Summary) & 48,76 & 43,51 & 42,19 & 45,60 & 53,91 & 38,24 & 45,38 \\
\hline Helyezés (Rank) & 2 & 5 & 6 & 3 & 1 & 7 & 4 \\
\hline
\end{tabular}


A házi párlat iránti fogyasztói attitűd kedvezőbb, mint a többi tömény szeszes italé. Habár a pálinkafogyasztás tényleges mértéke a házi párlatot érintő feketekereskedelem és a be nem jelentett házi fózések miatt nem mérhető, eredményeink egybecsengenek az AC Nielsen (VILÁGGAZDASÁG，2017) piackutató megállapításaival, miszerint hazánkban a keserú italok és a borpárlatok rendkívül népszerűek. A legfontosabbnak ítélt vásárlási szempont, a minőség tekintetében a bolti pálinka az utolsó és a házi párlat az első. Szembetűnő, hogy a magyar eredet szempontjából a házi párlat másfélszer annyi pontot kapott, mint a bolti pálinka, ami kognitív hiányosságokra utal. Ár tekintetében a házi párlatot tartották válaszadóink a legmegfelelőbbnek, a bolti pálinka iránti attitüd ebben a vonatkozásban a középmezőnyben található. A whiskyre a megkérdezettek magas minőségü és presztízsü, valamint divatos italként tekintenek.

$\mathrm{Az}$ eredmények alátámasztották előzetes elképzelésinket. Kérdőívünkben az attitűd komponensek részletes megismeréséhez a házi párlat, illetve bolti pálinka mellé a whiskyt választottuk összehasonlításul.

Vizsgálatunkban a kognitív komponens megismeréséhez a Fishbein-modell egy továbbfejlesztett változatát is alkalmaztuk (HAWKINS és MOTHERSBAUGH, 2012). Ebben a megközelítésben a tulajdonságoknak létezik egy ideális mértéke, amelyhez képest a további tulajdonságnövelés már nem jelentene nagyobb hasznosságot. A mikroökonómiából ismert határhaszon megközelítést alkalmazták az ún. ideális pont azonosítására a többtényezős modelleknél. A kognitív komponens vizsgálatára 16 állítást fogalmaztunk meg polaritás skála (Osgood skála) alkalmazásával. A kérdések konzisztenciáját mérő Cronbach-alfa (CRONBACH, 1951) értékek [ideális ital $(0,717)$, házi párlat $(0,770)$, bolti pálinka $(0,867)$, whisky $(0,757)]$ meghaladták a o,7-es értéket, amely szerint a kérdések megbízhatóan mérnek.

Az imázs gondolatokból, érzésekből, ítéletekből létrejött virtuális képződmény, azonban ahogyan SAS (2012) bemutatja, az imázs láthatóvá tételére többféle megoldást is választhatunk. Az egyik legelterjedtebb és legszemléletesebb módszer az imázsprofil alkalmazása, melyben a hétfokozatú szemantikai differenciál skálákon az ellentétpárokra felvett pontérték átlagait összekötjük, kirajzolva ezzel az adott termék imázsprofilját. Az 1. ábrán szemléltetjük a vizsgált három égetett szeszes ital, és az ideális tömény szeszes ital imázsprofiljait.

A 7 fokozatú szemantikai differenciál skálán a 16 ellentétpárra kapott válaszokat átlagoltuk, majd HAWKINS és MOTHERSBAUGH (2012) javaslata alapján kiszámoltuk a három italnak az ideálistól való távolságát (3. táblázat). Az attitűdindex annál kedvezőbb, minél közelebb van a nullához, vagyis az ideális italra, és az adott italra kapott válaszok abszolút értékben kifejezett különbsége a legkisebb.

A három ital aggregált értékei szerint a házi párlat attitűdindexe a legkedvezőbb $(13,41)$, ôt követi a whisky $(17,18)$, a megkérdezettek szerint a három ital közül a bolti pálinka felel meg legkevésbé az ideális égetett szeszes ital tulajdonságainak $(19,72)$. H3 hipotézisünk szerint a bolti pálinka kedvezőtlenebb imázzsal rendelkezik, mint a keserü italok, a vodka, és a whisky, amelyet kutatási eredményeink alátámasztottak.

Az ideális ital válaszadóink szerint illatban és fóleg ízben gazdag, nem túl drága, kellemes, selymes ízú, ami lehetőleg nem okoz másnaposságot. A speciális címke, illetve elegáns kiszerelés, valamint a speciális elérhetőség nem volt különösképpen fontos a megkérdezettek számára. Az ideális égetett szeszes ital lehetőleg legyen egészséges, ami szintén ismereti hiányosságokra utal. H1 hipotézisünkben azt feltételeztük, hogy a házi párlat imázsa pozitívabb, mint a bolti pálinkáé, melyet kutatási eredményeink alátámasztottak. Akárcsak a H2 hipotézist, mely szerint a pálinkával kapcsolatos ismeretek még mindig rendkívül hiányosak. Fontos kihangsúlyozni, hogy a whisky külföldi eredetével tisztában voltak a válaszadók, azonban a házi párlat és a bolti pálinka közötti magyar eredetre vonatkozó különbség elgondolkodtató. A kognitív komponens hiányosságára utal a bolti pálinka ízesítettként való megítélése is. A megkérdezettek mindhárom italt kesernyésebbnek, torkot kaparóbbnak gondolták az ideálisnál. Alkoholtartalom szempontjából a whisky közelítette meg leginkább az ideális mértéket. 
$\frac{1}{8}$

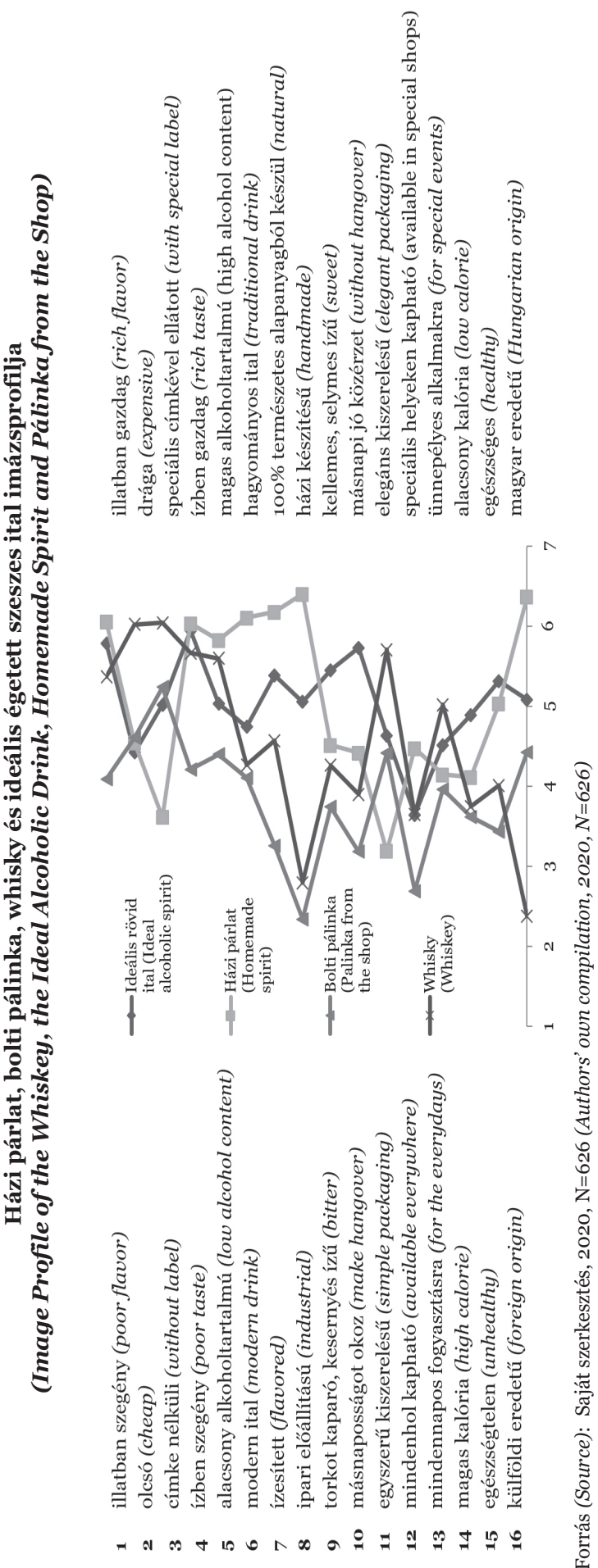


Házi párlat, bolti pálinka és whisky fogyasztói attitúdindex vizsgálata az ideális égetett szeszes ital meghatározásával

(Examination of the Consumer Attitude Index of Ideal Spirit, Whiskey, Homemade Spirit and Pálinka from the Shop)

\begin{tabular}{|c|c|c|c|c|c|c|c|}
\hline \multirow[b]{2}{*}{$\begin{array}{l}\text { Ellentét- } \\
\text { párok száma } \\
\text { (Number of } \\
\text { opposing } \\
\text { pairs) }\end{array}$} & \multicolumn{4}{|c|}{$\begin{array}{l}\text { Átlagok (1-7 Likert skála) } \\
\text { (Means, 1-7 Likert scale) }\end{array}$} & \multicolumn{3}{|c|}{$\begin{array}{c}\text { Ideálistól való távolság (abszolút } \\
\text { értékben kifejezve) } \\
\text { (Distance from the ideal in absolute } \\
\text { terms) }\end{array}$} \\
\hline & $\begin{array}{l}\text { Ideális } \\
\text { rövid ital } \\
\text { (Ideal } \\
\text { alcoholic } \\
\text { spirit) }\end{array}$ & $\begin{array}{l}\text { Házi } \\
\text { párlat } \\
\text { (Home- } \\
\text { made } \\
\text { spirit) }\end{array}$ & $\begin{array}{c}\text { Bolti } \\
\text { pálinka } \\
\text { (Palinka } \\
\text { from the } \\
\text { shop) }\end{array}$ & $\begin{array}{c}\text { Whisky } \\
\text { (Whiskey) }\end{array}$ & $\begin{array}{c}\text { Házi } \\
\text { párlat } \\
\text { (Home- } \\
\text { made } \\
\text { spirit }\end{array}$ & $\begin{array}{c}\text { Bolti } \\
\text { pálinka } \\
\text { (Palinka } \\
\text { from the } \\
\text { shop) }\end{array}$ & $\begin{array}{c}\text { Whisky } \\
\text { (Whiskey) }\end{array}$ \\
\hline 1. & 5,78 & 6,05 & 4,09 & 5,37 & 0,27 & 1,69 & 0,41 \\
\hline 2. & 4,42 & 4,54 & 4,61 & 6,02 & 0,12 & 0,19 & 1,60 \\
\hline 3. & 5,02 & 3,61 & 5,23 & 6,04 & 1,41 & 0,22 & 1,02 \\
\hline 4. & 5,95 & 6,03 & 4,21 & 5,66 & 0,09 & 1,74 & 0,28 \\
\hline 5. & 5,03 & 5,82 & 4,40 & 5,60 & 0,79 & 0,64 & 0,56 \\
\hline 6. & 4,74 & 6,10 & 4,11 & 4,27 & 1,36 & 0,64 & 0,47 \\
\hline 7. & 5,38 & 6,18 & 3,26 & 4,57 & 0,79 & 2,13 & 0,82 \\
\hline 8. & 5,05 & 6,40 & 2,34 & 2,79 & 1,35 & 2,71 & 2,26 \\
\hline 9. & 5,45 & 4,51 & 3,74 & 4,26 & 0,93 & 1,71 & 1,19 \\
\hline 10. & 5,73 & 4,42 & 3,18 & 3,90 & 1,31 & 2,55 & 1,83 \\
\hline 11. & 4,63 & 3,19 & 4,41 & 5,71 & 1,44 & 0,22 & 1,07 \\
\hline 12. & 3,64 & 4,47 & 2,69 & 3,65 & 0,83 & 0,96 & 0,00 \\
\hline 13. & 4,51 & 4,15 & 3,96 & 5,02 & 0,37 & 0,55 & 0,50 \\
\hline 14. & 4,89 & 4,11 & 3,62 & 3,74 & 0,77 & 1,27 & 1,14 \\
\hline 15. & 5,31 & 5,03 & 3,43 & 4,01 & 0,29 & 1,88 & 1,30 \\
\hline 16. & 5,08 & 6,36 & 4,42 & 2,38 & 1,28 & 0,66 & 2,70 \\
\hline
\end{tabular}

Forrás (Source): Saját szerkesztés, 2020, N=626 (Authors' own compilation, 202O, N=626)

Kalóriatartalom tekintetében viszonylag egyformának ítélték meg az italokat, a megkérdezettek szerint az ideális rövid ital alacsony kalóriatartalommal rendelkezik. Az ideális ital inkább házi készítésű, amely kritériumnak a házi párlat felelt meg. A kereskedelmi pálinkák csak modernségben, és a kalóriatartalom megítélésében veszik fel a versenyt a whiskyvel, minden egyéb szempont alapján kedvezőtlenebb megítélés alá esnek. A fogyasztási alkalom szempontjából majdnem egyforma értékeket kaptunk, legünnepélyesebb ital a whisky. Eredményeink alátámasztják az eddigi kutatások (TOTTH, 2009; FODOR et al., 2011; SZEGEDYNÉ et al., 2017; TOTTH et al., 2017) megállapításait, miszerint a hazai fogyasztók pálinkával kapcsolatos tudása, ismerete nem csak hiányos, hanem téves is. Válaszadóink nincsenek meggyőződve a pálinka magyar eredetéről, ráadásul ebben a tekintetben is erős különbség van a házi párlatok javára. A kereskedelmi pálinkák a megkérdezettek szerint csak elegáns kiszerelésükkel tudják a házi párlatot felülmúlni.

A pálinkafogyasztás még alaposabb megismeréséhez a demográfiai háttérváltozók tekintetében további imázsprofilokat készítettünk, amelyeket terjedelmi okokból nem tudunk megjeleníteni. A továbbiakban a legfontosabb eredményeket emeljük ki. Nemek tekintetében a nóknek az ital illat gazdagságát tekintve az ideálishoz a házi párlat állt a legközelebb, férfiaknál a whisky. A férfiaknak a speciális címke kevésbé fontos, mint a nőknek, akiknek ilyen 
szempontból a bolti pálinka teljes mértékben megfelel. A nők TOTTH és SZOLNOKI 2019es, borral kapcsolatos vizsgálatában is hasonlóképpen vélekedtek a címke fontosságáról. A nők a kevesebb alkoholtartalmat tartják ideálisnak, ebból a szempontból számukra a bolti pálinka a legmegfelelőbb ital, a férfiak a magasabb alkoholtartalmú italt részesítik előnyben, mely igényt számukra teljes mértékben kielégít a whisky. Sajnos mindkét nem egyformán tájékozatlan a magyar eredet és az ízesítettség vonatkozásában, ráadásul a kereskedelmi pálinka még a másnaposság megítélésében is a legroszszabbul teljesít. Az életkor növekedésével a másnaposság elkerülése egyre nagyobb fontosságot kap, melynek minden korcsoport megítélésében a házi párlat felel meg leginkább. A 35-44 éves valamint a 45-54 éves korcsoportok számára címke, ár és modernség tekintetében a bolti pálinka áll legközelebb az ideálishoz. További jó hír a kereskedelmi pálinka gyártóinak, hogy termékeik a fiatalabb korosztály megítélésében megfelelnek az ideális elegáns kiszerelésnek.

\section{KÖVETKEZTETÉSEK ÉS}

\section{JAVASLATOK - CONCLUSIONS AND}

\section{PROPOSALS}

Jelen tanulmányban a pálinkaimázst befolyásoló fogyasztói attitűd komponensek kognitív dimenziójára koncentráltunk. A szakirodalom (HOFMEISTER-TÓTH, 2006; HAWKINS és MOTHERSBAUGH, 2012; SAS, 2012) szerint a vásárlók különböző termékekkel, márkákkal szembeni attitűdjének megváltoztatása, módosítása a marketingkommunikáció feladata. Sok esetben a vállalatok úgy próbálják befolyásolni a fogyasztók márkák iránti érzéseit, hogy közvetlenül nem befolyásolják sem a meggyőzódésüket, sem pedig a magatartásukat, hanem a vállalat/márka sikeressége az, ami a fogyasztói kötődést maga után vonja. A pálinkához kapcsolódó attitűd megváltoztatása többszintű kihívást jelent, hiszen az ismeretek mind a pálinka, mind a házi párlat vonatkozásában hiányosak és tévesek.

$\mathrm{Az}$ egyik legfontosabb marketingfeladat elősegíteni a termék megvásárlását, de ter- mészetesen arról is gondoskodni kell, hogy a termék fogyasztása, használata stb. elégedettséghez vezessen. A jelen tanulmányban vizsgált kognitív attitűd komponens befolyásolásában általában a kognitív tanulás folyamata és a fogyasztók megfelelő információval történó ellátása segíthet. A hazai fogyasztók pálinkával kapcsolatos ismereteinek, meggyőződéseinek kedvező irányba történő elmozdítása a piaci szereplők fontos feladata.

\section{6. ÖSSZEFOGLALÁS - SUMMARY}

A kutatás célja a hazai pálinkafogyasztás, valamint a pálinkához kapcsolódó imázs megismerése volt. A korábbi hazai kutatásokhoz képest új megközelítést alkalmaztunk, melyben a fogyasztói attitűd komponensek imázs kialakító szerepét vizsgáltuk a bolti pálinkára, valamint a házi párlatra koncentrálva. A szakirodalom tanulmányozását követően kvalitatív vizsgálatot végeztünk, amely feltárta a kvantitatív kutatás legfontosabb aspektusait. A kvantitatív vizsgálat standard kérdőívezés volt, kvótás mintavétel módszerével, a minta 626 érvényes kitöltővel nem, korcsoport, és régió szempontjából megegyezik a 18 év feletti magyarországi lakosság összetételével.

A Magyarországon legtöbbet fogyasztott égetett szeszes italokhoz kapcsolódó fogyasztói attitűd mérésére Fishbein attitűd modelljét alkalmaztuk. Az összehasonlításban a vizsgált hét ital közül a házi párlat rendelkezett a legkedvezóbb attitúddel, a bolti pálinka pedig a legkedvezőtlenebbel. A kereskedelmi pálinka gyártóinak további rossz hír, hogy a fogyasztói attitűd kognitív komponensét részletesen vizsgálva megállapítottuk, hogy a bolti pálinkának a házi párlatokhoz képesti rossz imázsa mögött ismereti, tudásbeli hiányosságok és tévedések húzódnak meg. A bolti pálinka helyzetének a javítása, a piaci szereplők versenyképességének a növelése átfogó marketingstratégiát igényel. Az attitűd komponensekre vonatkozó kutatásunk jelen tanulmánnyal összefüggő további eredményeit - melyben az attitűd affektív és konatív komponenseit vizsgáljuk a pálinkafogyasztás vonatkozásában - egy későbbi publikációban ismertetjük majd. 


\section{IRODALOMJEGYZÉK - REFERENCES}

2008. évi LXXIII. törvény: A pálinkáról, a törkölypálinkáról és a Pálinka Nemzeti Tanácsról. 2008. URL: https://net. jogtar.hu/jogszabaly?docid=ao800073.tv (Letöltés dátuma: 2019.10.10.)

Allport, G.: Attitudes. 1935. Az attitűd pszichológiai kutatásának kérdései. (Szerk: Halász, L. - Hunyadi, Gy. - Marton, L.) Akadémiai Kiadó, Budapest, 1979.

Alsamydai, M. J. - Hmod, S. - Suaad, A: Measuring Customers' Attitudes Toward Banking Services Offered by Iraqi Public and Private Commercial Banks. International Journal of Business Management Research. 2014. 4 (2) 109124.

Authman, Y. R.: Approche Marketing $\mathrm{Du}$ Comportement De Consommateur, Test De Different Models Appliqués Aux Produits Electro-Managers, These Doctorate D'etates-Sciences De Gestion, Universite Clermont I, France, 1986. 3742.

Brijs, K. - Bloemer, J. - Kasper, H.: Country-Image Discourse Model: Unraveling Meaning, Structure, and Function of Country Images. Journal of Business Research. 2011. 64 (12) 12591269. DOI: https://doi.org/10.1016/j. jbusres.2011.01.017

Bruhn, M.: Integrierte Kommunikation in den deutschsprachigen Ländern. 7th International Science Marketing Trends Congress, Venice, 2008.

Cronbach, L. J.: Coefficient Alpha and the Internal Structure of Tests. Psychometrika. 1951. 16 (3) 297-334. DOI: https://doi. org/10.1007/bfo2310555

Eagly, A. - Chaiken, S.: The Psychology of Attitudes. Harcourt Brace Jovanovich: Fort Worth, TX, USA, 1993.

Elliot, S. - Papadopoulos, N. - Kim, S. S.: An Integrative Model of Place Image: Exploring Relationships Between Destination, Product, and Country Images. Journal of Travel Research. 2011. 50 (5) 520-534. DOI: https://doi. org/10.1177/0047287510379161
Fishbein, M. - Ajzen, I.: Beliefs, Attitude, Intention, and Behavior, an Introduction to Theory and Research. Reading. MA: Addison-Wesley, 1975.

Fishbein, M.: A Behavior Theory Approach to the Relations Between Beliefs About an Object and Attitude Toward the Object. John Wiley \& Sons, New York, 1967.

Fodor, M. - Hlédik, E. - Totth, G.: Fogyasztói vélemények és preferenciák a pálinka piacán. Élelmiszer, Táplálkozás és Marketing. 2011.8 (1-2) 41-47.

Gutjahr, G.: A piaclélektan kézikönyve. Aula Kiadó, Budapest, 1992.

Hawkins, D. I. - Mothersbaugh, D. L.: Consumer Behaviour. McGraw-Hill Education, 2012. 416-418.

Hofmeister-Tóth, Á.: $\quad$ Fogyasztói magatartás. Aula Kiadó, Budapest, 2006.

Jónás, J.: Mesterpálinkák, pálinkamesterek. Korona Kiadó, Budapest, 2006.

Kontor, E. - Kovács, B. - Szakály, Z. Kiss, M.: A védjegyekkel kapcsolatos attitűd és az életstílusjegyek összefüggései. Statisztikai Szemle. 2019. 97 (4) 364386. DOI: https://doi.org/10.20311/ stat2019.4.huo36

KSH: A lakónépesség korcsoport szerint, január 1. (2001-). 2019a. URL: https:// www.ksh.hu/docs/hun/xstadat/xstadat eves/i_wdsdoo4c.html (Letöltés dátuma: 2019.10.10.)

KSH: A lakónépesség nem szerint, január 1. (2001-). 2019b. URL: https://www. ksh.hu/docs/hun/xstadat/xstadat eves/i_wdsdoo3c.html (Letöltés dátuma: 2019.10.10.)

Lakner, Z. - Hajdu, I.-NÉ - Kajári, K. Kasza, Gy. - Márkusz, P. - Vízvári, B.: Versenyképes élelmiszergazdaság élhető vidék. Gazdálkodás. 2007. 51 (802016-609) 1-13.

Lakner, Z. - Hajdu, I.-NÉ - Kolcsiter, G.: Az átalakuló élelmiszer-kereskedelem és a fogyasztó I. rész. Élelmezési Ipar. 2004. 58 (8) 229-232.

Lars, P.: Consumer Behavior: The Psychology of Marketing. Department of Marketing Marshall School of Business University of Southern California, Los Angeles, 2012. 
Lehota, J.: Élelmiszergazdasági marketing. Müszaki Könyvkiadó, Budapest, 2001.

Malota, E.: Fogyasztói etnocentrizmus. A sztereotípiák, az etnocentrizmus és az országeredet imázs hatása a hazai és a külföldi termékek megítélésére (Doctoral dissertation, Budapesti Corvinus Egyetem). 2003. 12.

Mandy, M. - T, Tang - Esther, P. Y.: Consumer Attitude Towards Mobile Advertising, the Role of Permission. International Academy of Business and Economics Audience, 2008. 8.

Miklós, I.: A vásárlói értékek és a gyenge elköteleződések az élelmiszerpiacon. Táplálkozásmarketing. 2019. 6 (1) 25-40. DOI: https://doi.org/10.20494/TM/6/1/2

Nathan, M. - Eleanor, E. M.: Encyclopedia of Consumer Culture. Attitude Theory. 2011. 1 (4) 1664.

Nijssen, E. - Douglas, S.: Consumer World-Mindedness and Attitudes Toward Product Positioning In Advertising: An Examination of Global Versus Foreign Versus Local Position. Journal of International Marketing. 2011. 19 113-133. DOI: https://doi.org/10.1509/ jimk.19.3.113

Oliver, R. - Swan, J.: Consumer Perceptions of Interpersonal Equity and Satisfaction in Transactions: A Field Survey Approach. Journal of Marketing. 1989. 53 21-35. DOI: https://doi. org/10.1177/002224298905300202

Olson, J. M - Zanna, M. P.: Attitudes and Attitude Change. Annual Review of Psychology. 1993. 44 117-154. DOI: https://doi.org/10.1146/annurev. ps.44.020193.001001

Pálinka Nemzeti Tanács: Ki fogja végezni a kormány a pálinkafózést. 2019. URL: https://www.palinkanemzetitanacs.hu/ hu/aktualitasok/42 (Letöltés dátuma: 2020.02.12.)
Reza, M. - Douglas, I. M.: The Relations Among Attribute and Importance Components of Rosenberg- Fishbein Type Attitude Model: An Empirical Investigation. Proceedings of the Second Annual Conference of Association for Consumer Research. Proceedings of the Second Annual Conference of the Association for Consumer Research. 1971. 365-375.

Sas, I.: Reklám és pszichológia a webkorszakban - Upgrade 3.0. Kommunikációs Akadémia Kft, Budapest, 2012.

Szakály, Z. - Szigeti, O. - Szente, V.: Hagyományos magyar termékek marketinglehetőségeinek elemzése a vidékfejlesztés szempontjainak figyelembe vételével. Európai Tanulmányok. Tas Kiadó, Budapest, 2004.

Szegedyné, F. Á. - Szakos, D. - Bódi, B. Kasza, Gy.: Pálinka, fogyasztói ismeretek, preferenciák, fogyasztói szokások, marketinglehetőségek. Gazdálkodás. 2017. 60 (2) 158-170.

Szeles, P.: A hírnév ereje. STAR PR, Budapest, 1998.

Szeles, P. (Szerk.): Nagy PR könyv. Management Kiadó, Budapest, 2001.

Tomcsányi, P.: Az élelmiszer-gazdasági marketing alapjai. Mezőgazdasági Kiadó, Budapest, 1988.

Totth, G. - Mezőné, Oravecz, T. - Zarándné, Vámosi, K.: A pálinkafogyasztás és a fogyasztói szokások változása. Prosperitas. 2018a. 2018/2. 87-98. DOI: https://doi.org/10.31570/ Prosp_2018_02_5

Totth, G. - Mezőné, Oravecz, T. Zarándné, Vámosi, K.: A pálinka fogyasztási és vásárlási szokásainak kvalitatív vizsgálata. Prosperitas. 2018b. 2018/2. 99-115. DOI: https://doi. org/10.31570/Prosp_2018_02_6 
Totth, G.: A vállalati imázs kialakításának és fenntartásának módszertana. BKE Vezetőképző Intézet, Budapest, 1996.

Totth, G.: Stratégiai kihívások a megváltozott gazdasági környezetben a minőségi pálinka hazai forgalmazásában. In: Losoncz, M. - Solt, K. - Szigeti, C. (szerk.): Kautz Gyula emlékkötet: Halálának 100. és születésének 180. évfordulója alkalmából. Győr: Széchenyi István Egyetem, 2009.

Totth, G. - Hlédik, E. - Zarándné, Vámosi, K.: A védjegyek szerepe a vásárlási döntésekben. In: Marketing hálózaton innen és túl. Az Egyesület a Marketing Oktatásért és Kutatásért XXI. országos konferenciájának tanulmánykötete (Szerk.: Bíró-Szigeti, Sz. - Petruska, I. - Szalkai, Zs. - Kovács, I. - Magyar, M.). Budapesti Műszaki és Gazdaságtudományi Egyetem, Budapest, 2015. 136-144.

Totth, G.: A vállalati image vizsgálatok. Kandidátusi értekezés. Budapesti Közgazdaságtudományi Egyetem, Budapest, 1994.
Totth, G.: A piaci hírnév hordozói. Agrofüzetek, 3., 1998.

Totth, G. - Kovács, I. - Mezőné, Oravecz, T. - Zarándné, Vámosi, K.: A fiatalok pálinkafogyasztási szokásai. In: Tükröződés, társtudományok, trendek, fogyasztás: Egyesület a Marketing Oktatásért és kutatásért (EMOK) XXIII. országos konferencia (Szerk.: Bányai, E. Lányi, B. - Törőcsik, M.) Tanulmánykötet. 2017. 230-238.

Totth, G. - Szolnoki, G.: A magyarországi borfogyasztói szokások és a borpiac elemzése. Gazdálkodás. 2019. 63 (802019-580) 22-39.

Világgazdaság: Töménybe ölt tízmilliárdok. 2017. URL: https://www.vg.hu/gazdasag/ tomenybe-olt-tizmilliardok-2-670247/ (Letöltés dátuma: 2019.10.20.)

Youn, S. - Kim, H.: Antecedents of Consumer Attitudes Toward CauseRelated Marketing. Journal of. Advertising Research. 2008. 48 (1) 123-137. DOI: https://doi.org/10.2501/ Soo21849908080136

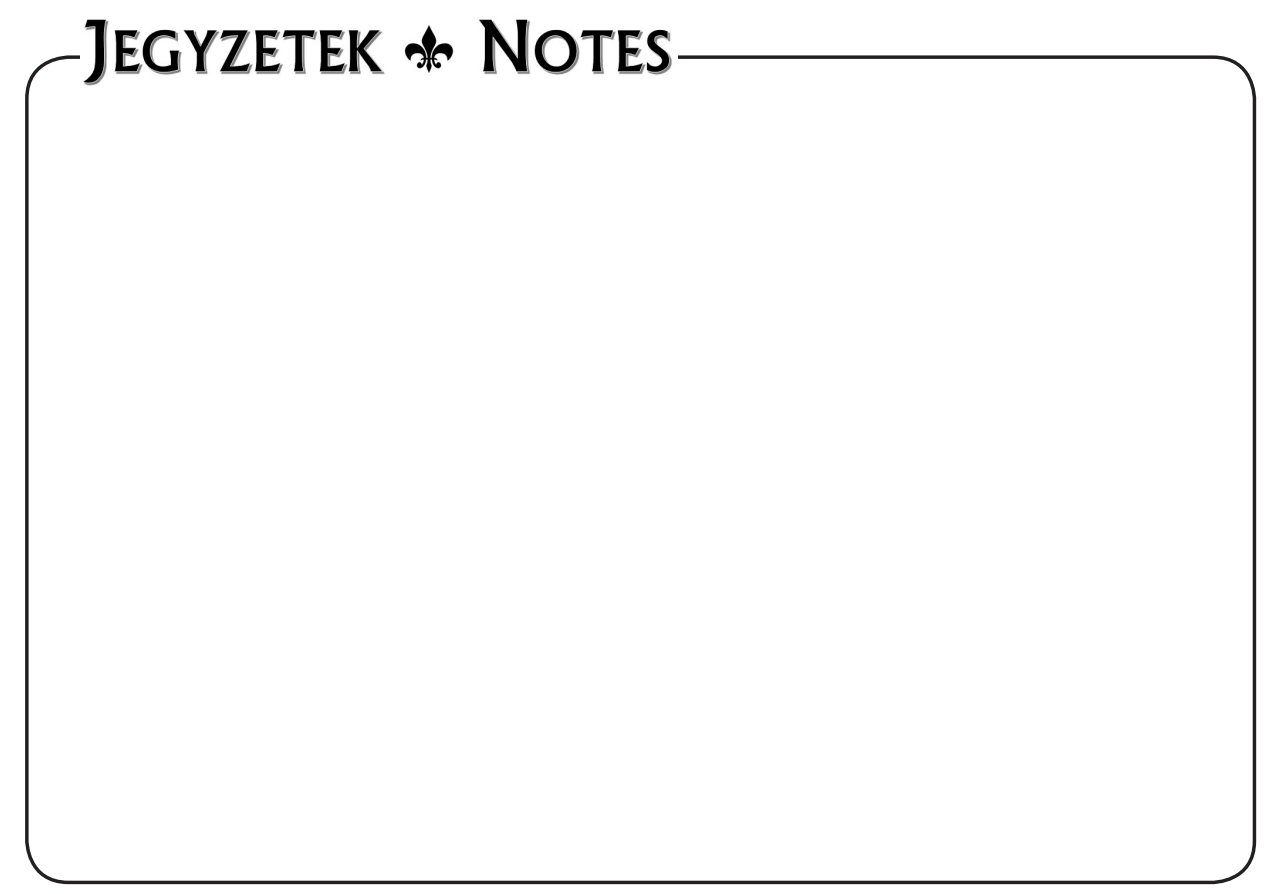

